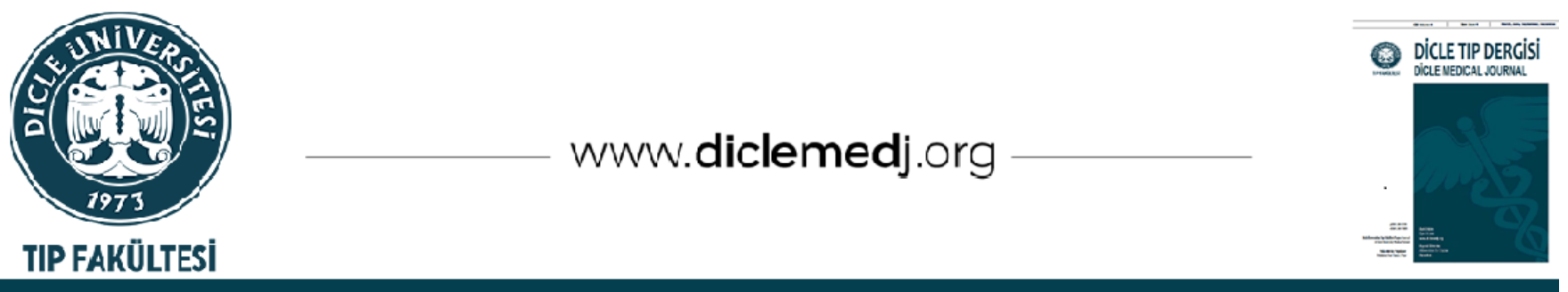

Original Article / Özgün Araştırma

\title{
The Role Of Breast-Conserving Surgery In The Treatment Of Early- Stage Breast Cancer
}

\author{
Fatih Çiftci ${ }^{i}{ }_{1}$, Mehmet Tolga Kafadar ${ }^{D_{2}}$ \\ 1 Istanbul Gelisim University Institute of Health Sciences, Istanbul, Turkey \\ 2 Dicle University School of Medicine Department of General Surgery, Diyarbakır, Turkey \\ Received: 01.10.2020; Revised: 25.11.2020; Accepted: 25.11.2020
}

\begin{abstract}
Objective: In the treatment of early-stage breast cancer, breast-conserving surgical treatment has been increasingly used. In our study, we investigated the survival efficacy in the long-term follow-up of breast-conserving surgical treatment in patients without axillary lymph node metastasis.

Method: Thirty-nine patients without axillary lymph node metastasis who had undergone surgery for infiltrating ductal breast cancer between 2009 and 2018 were recordedin the research. Of these patients, 23 (58.9\%) undergo MRM (modified radical mastectomy)and $16(41.0 \%)$ undergo BCS (breast-conserving surgery). All of the patients who underwent BCS were given radiotherapy, and the patients with T2 and T3 tumors in two groups were given adjuvant chemotherapy and hormonotherapy according to receptor status. The patients were followed up by physical examination and imaging methods every three months in the first two years and then every six months.
\end{abstract}

Results: All patients were followed up during the study (6 - 96 months). There was not variations between the 2 groups in terms of patient age, tumor localization, menopausal status, and the number of lymph nodes dissected. Local recurrence was detected in 1 (6.2\%) patient who underwent BCS and was treated with a total mastectomy. In another patient, lung and liver metastases were detected in the 7th year. Infiltrative ductal carcinoma of the contralateral breast was detected in $3(13 \%)$ patients who underwent MRM between 12-24 months. No patients were lost in either group.

Conclusion: In patients with early breast cancer, BCS was found to be disease-free and as safe as MRM surgeries for overall survival.

Keywords: Breast-conserving surgery, breast cancer, modified radical mastectomy

DOI: 10.5798/dicletip.850378

Correspondence / Yazışma Adresi: Fatih Çiftci, Istanbul Gelisim University, Insitutue of Health Sciences, Avcılar, Istanbul, Turkey e-mail: oprdrfatihciftci@gmail.com 


\section{Erken Evre Meme Kanseri Tedavisinde Meme Koruyucu Cerrahinin Rolü}

Öz

Amaç: Meme koruyucu cerrahi erken evre meme kanserinin tedavisinde gün geçtikçe daha fazla kullanılmaktadır. Çalışmamızda koltuk altı lenf nodu metastazı olmayan hastalarda meme koruyucu cerrahi tedavinin uzun süreli takibinde sağkalım etkinliğini araştırdık.

Yöntemler: 2009-2018 yılları arasında aksiller lenf nodu metastazı olmayan ve infiltrative ductal meme kanseri ameliyatı geçiren 39 hasta çalışmaya dahil edildi. Bu hastaların 23'üne (\%58.9) modifiye radikal mastektomi(MRM), 16'sına (\%41.0) meme koruyucu cerrahi (MKC) uyguland. MKC yapılan tüm hastalara radyoterapi, iki gruptaki T2 ve T3 tümörlü hastalara reseptör durumuna göre adjuvant kemoterapi ve hormonoterapi verildi. Hastalar ilk 2 yll ve 3 ayda bir ardından 6 ayda bir fizik muayene ve görüntüleme yöntemleriyle takip edildi.

Bulgular: Tüm hastalar çalışma süresince (6-96 ay) takip edildi. İki grup arasında hasta yaşı,tümör lokalizasyonu, menapoz durumu ve diseke edilen lenf nodu bakımından fark yoktu. MKC yapılan ve total mastektomi uygulanan 1(\%6.2) hastada lokal nüks tesbit edildi. Diğer bir hastada 7.yılda akciğer ve karaciğer metastazı saptandı. 12-24 ay arasında MRM yapılan 3(\%13) hastada memede infiltrative duktal karsinom saptandı. Her iki grupta da kaybedilen hasta olmadı.

Sonuç: Erken evre meme kanseri olan hastalarda MKC'nin hastalıksız ve genel sağkalım açısından MRM ameliyatı kadar güvenli olduğu söylenilebilinir.

Anahtar kelimeler: meme koruyucu cerrahi, meme kanseri, modifiye radikal mastektomi.

\section{INTRODUCTION}

Breast cancer accounts for $50 \%$ of cancers observed in women aged 40 - 55 years. Although its incidence increases, the mortality rate due to breast cancer decreases thanks to the more frequent use of screening methods ${ }^{1}$. The use of regular mammography for screening purposes has been reported to reduce the mortality rate by $29 \% 2$.

Nowadays, it is accepted that the action of breast cancer is local development in some patients and systemic from the beginning in some others, unlike Halsted ${ }^{3}$ or Fisher's 4 theories. Therefore, the surgical method used for local control is gaining popularity from modified radical mastectomy to breastconserving surgery.

In this study, we compared the survival efficacy of modified radical mastectomy and breastconserving surgery in patients without axillary lymph node metastasis.

\section{METHODS}

From July 2009 to January 2018, 109 patients underwent surgical treatment for infiltrating ductal breast cancer in our clinic. The research was approved by University Ethics Committee with the number 10.11.2018.E.3955. The surgical procedure was performed as a modified radical mastectomy (MRM) or breastconserving surgery (BCS) after the patients were informed about the surgery and their informed consent was signed according to the choice made with the discussion of the surgeon and the patient. In this retrospective study, among the patients who undergo surgery for breast cancer, patients with at least ten lymph nodes dissected by axillary dissection, without metastasis, who had no distant metastasis, were recorded in the study.

Patients with fewer than ten lymph nodes dissected by axillary dissection, who had lymph node metastasis even if a sufficient number of lymph nodes were dissected or known distant metastasis before surgery were not included in the study. Furthermore, as a clinical protocol, in breast-conserving surgery, it was accepted that the tumor should be at least $1 \mathrm{~cm}$ from the surgical margin. It was decided at the end of routine pathological examination whether or 
not this requirement was complied with. In our clinic, the lumpectomy method is preferred as the BCS protocol and axillary dissection is performed through a separate incision.

Clinically, multicentricity and central localization of the tumor constituted the reasons for not preferring BCS. Moreover, since some of the patients resided in the countryside, they preferred MRM because of difficulties in receiving radiotherapy. All patients who underwent BCS received radiotherapy and the patients with $\mathrm{T} 2$ and $\mathrm{T} 3$ tumors in two groups received anthracycline-containing adjuvant chemotherapy and hormonotherapy according to receptor status in the postoperative period.

The patients were followed up using imaging methods including physical examination, chest x-ray, upper abdomen and breast ultrasonography and mammography every three months in the first two years and then every six months.

Patients who undergo MRM and BCS were retrospectively compared to local recurrence and distant metastasis. The statistical analyses were applied using the chi-square test and Student's t-test with the help of SPSS 18.0 packaged software. The Kaplan-Meier procedure was used for survival times, and logrank tests were used to their comparisons.

\section{RESULTS}

Of 109 patients who had undergone surgical treatment for infiltrating ductal breast cancer between June 2009 and January 2018, 39 patients who complied with the study criteria were evaluated retrospectively. Of these patients, 23 (58.9\%) underwent a modified radical mastectomy (MRM), and 16 (41.0\%) underwent breast-conserving surgery (BCS). In all 16 patients who underwent BCS, it was observed that a $1 \mathrm{~cm}$ safety margin target was achieved after the pathological examination. Therefore, none of the patients underwent MRM for resection or margin violation. No family history was found in any of the patients recorded in the study.

While BCS was applied to $4(57.1 \%)$ patients and MRM was applied to $3(42.9 \%)$ patients under 40 years of age, the rates of BCS and MRM in patients over 40 years of age were $37.1 \%$ (n:13) and $62.9 \%$ (n:22), respectively $(\mathrm{p}=0.000)$. The median age was $50.9 \pm 9.9$ and $51.6 \pm 14.0$ in the MRM and BCS groups, respectively $(\mathrm{p}=0.865) \quad$ (Table $\mathrm{I})$. The menopausal status of the patients is shown in Table 1. Eighteen $(72 \%)$ of the patients who underwent MRM and eight (47\%) of those who underwent BCS were living in a town or village outside the city center.

Table I: Status of the patients in both groups SD: Standart deviation

\begin{tabular}{|l|l|l|l|}
\hline & $\begin{array}{l}\text { Modified } \\
\text { Radical } \\
\text { Mastectomy }\end{array}$ & $\begin{array}{l}\text { Breast- } \\
\text { Conserving } \\
\text { Surgery }\end{array}$ & P-value \\
\hline Median age \pm SD & $51.1 \pm 8.8$ & $50.9 \pm 13.9$ & 0.859 \\
\hline $\begin{array}{l}\text { Rate of patients } \\
\text { under 40 years of } \\
\text { age(\%) }\end{array}$ & 41.8 & 56.9 & 0.000 \\
\hline $\begin{array}{l}\text { Menopausal status } \\
\text { (pre/peri/post) }\end{array}$ & $9 / 5 / 9$ & $6 / 1 / 9$ & 0.410 \\
\hline
\end{tabular}

The tumor was located on the left side in 12 patients, on the right side in 8 patients, and bilaterally in 3 patients. Bilaterally located tumors appeared as a second primary tumor in the other breast after 6-24 months. In the BCS group, the tumor was in the left breast in 6 patients and in the right breast in 10 patients $(p=0.199)$. According to the TNM classification, the tumor had $\mathrm{T} 1, \mathrm{~T} 2$, and $\mathrm{T} 3$ diameters in 7,11, and 5 patients, respectively, in the MRM group. In the BCS group, the tumor had T1, T2, and T3 diameters in 7, 7, and 2 patients, respectively $(\mathrm{p}=0.030)$ (Table II). However, BCS $(66.7 \%)$ was preferred more than MRM (33.3\%) for stage I patients $(p=0.027)$. Tumor localization and the number of lymph nodes dissected are shown in Table II. There was no difference between the two groups in terms of tumor localization, menopausal status, and the number of lymph nodes dissected. As the protocol of the study, none of the patients in this study had metastatic lymph nodes. 
Table II: Tumor characteristics of the patients in both groups SD: Standart deviation

\begin{tabular}{|c|c|c|c|}
\hline & \begin{tabular}{|ll} 
Modified & Radical \\
Mastectomy & \\
\end{tabular} & $\begin{array}{l}\text { Breast-Conserving } \\
\text { Surgery }\end{array}$ & P-value \\
\hline Tumor localization (right/left/bilateral) & $8 / 12 / 3$ & $10 / 6 / 0$ & 0.199 \\
\hline 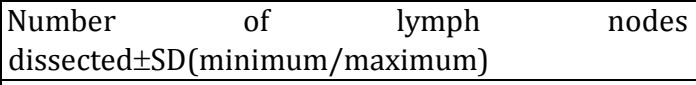 & $16.1 \pm 4.7(10-25)$ & $16.2 \pm 8.1(10-37)$ & 0.929 \\
\hline Cellular grade (I/II/III) & $7 / 11 / 5$ & $7 / 7 / 2$ & 0.470 \\
\hline \begin{tabular}{|lrr}
$\begin{array}{l}\text { Average } \quad \text { tumor } \\
\pm \text { SD(largest/smallest) }\end{array}$ & diameter & $(\mathrm{mm})$ \\
\end{tabular} & $31.01 \pm 15.80(5-41)$ & $24.01 \pm 7.95(15-41)$ & 0.079 \\
\hline Tumor stage (Stage I/II) & $4 / 19$ & $9 / 8$ & 0.030 \\
\hline
\end{tabular}

All patients were followed-up during the study. All of the patients in this study group completed the adjuvant chemotherapy and radiotherapy treatment required. The mean follow-up period was 62.4 (6-96) months. Local recurrence was detected in $1(5.8 \%)$ patient who underwent BCS, and a total mastectomy was applied. In 1 (5.8\%) patient, lung and liver metastases were detected in the 80th month. The median survival time of these patients was $84 \pm 3$ months. In $4(16 \%)$ patients who underwent MRM, infiltrative ductal carcinoma was detected as a result of pathological examination together with a new primary tumor in the contralateral breast between 6-24 months. All four patients underwent MRM of that breast. In this group, all patients were disease-free and alive during the follow-up period. There was not statistical difference both of the 2 groups in terms of local recurrence and distant metastasis (log-rank $\mathrm{p}=0.280$ ). No patients were lost in either group during the follow-up period.

\section{DISCUSSION}

It is thought that 5 million women worldwide are affected by breast cancer, of which incidence is increasing and which is becoming more common nowadays 5 . In patients who women with breast cancer, breast-conserving surgery (together with radiotherapy) has been of great benefit in reducing the already existing trauma in patients, at least in cosmetic terms and improving the quality of life $\mathrm{e}^{6}$. Most of studies have examined whether breast-conserving surgery performed together with radiotherapy has achieved this goal. However, more importantly, it has been investigated whether this method is riskier in terms of survival than mastectomy. Retrospective and randomized studies did not find a difference in survival between these two methods. Similar results were obtained in 12-year and 20-year follow-up studies comparing these two methods ${ }^{7-10}$.

After the results of these studies with large patient groups, it is observed that breastconserving surgery has been increasingly used, while many patients who are suitable for breast-conserving surgery or who do not have contraindications do not benefit from this option $^{11-12}$. This choice may be related to the size of the tumor as well as race, age, race, socioeconomic status of the patient, and the attitude of the surgeon and the hospital. In a series of high volume patients, $47.3 \%$ of the patients underwent breast-conserving surgery ${ }^{13-14}$. In this series, $7 \%$ of patients were under 40 years of age, while $51 \%$ were over 60 years of age. BCS has been reported to provide very good local control and survival, especially in elderly patients ${ }^{15}$. In our series, BCS was applied more to young people with aesthetic concerns. Since the patient's desire is also taken into consideration in the decision-making process, we can assume that younger patients (under 40 years) prefer BCS and older (over 40 years) patients prefer MRM. Furthermore, it is observed that BCS is also applied to patients living in the city center. 
One of the most important factors in the selection of BCS is the size of the tumor. In one study, according to the cancer research findings, $58 \%$ of patients with tumors smaller than $2 \mathrm{~cm}$ underwent BCS, and 42\% underwent MRM, while BCS and MRM rates in patients with tumors larger than $5 \mathrm{~cm}$ were $10 \%$ and $89 \%$, respectively $(\mathrm{p}<0.0001) 16$. In our series, according to our clinical protocol, no BCS was applied to tumors larger than $5 \mathrm{~cm}$. This choice isn't limited to tumor size but also depends on the stage of the tumor. In the selection of the surgery to be performed within the framework of the protocol applied in our clinic, BCS is performed more in early-stage breast cancers during the decision-making process of the patient and the surgeon who will perform the operation together. There is no consensus on the largest tumor size to which BCS can be applied. However, there is almost a consensus that there should be compatibility between tumor size and breast size. In this sense, patients with small breasts can rarely tolerate BCS cosmetically in tumors larger than $3 \mathrm{~cm}$.

Interestingly, BCS is less commonly applied in patients with a low socioeconomic level. In many studies, it was found that MRM was performed more than BCS in patients with a low socioeconomic level ${ }^{15-18}$. This difference is likely to be caused by difficulties in completing radiotherapy treatment, and problems with transport or order in working life.

The local recurrence problem after BCS is the weak spot of this method. In many studies, the local recurrence rate varies between $5-20 \% 19,20$. In a meta-analysis of 50 patients with early breast cancer in a study organized by the American National Cancer Institute (NCI), it was determined that the presence of positive surgical borders and high-grade carcinoma "in situ," the young age and the absence of radiotherapy in the postoperative treatment increased local recurrence ${ }^{21}$. In a study conducted in our country, multivariate analysis showed that the only factor associated with local recurrence was a positive surgical margin $^{22}$. However, the other author claimed that only positive lymph node metastasis and the presence of negative estrogen receptors increased the risk of in the local area recurrence after BCS.

It is reported that the presence of positive lymph nodes increases the risk of local area recurrence 3 times, and distant metastasis occurs in \%50 of the patients with local area recurrence. To reduce this relative increase in local recurrence, it is recommended that chemotherapy should be added to the treatment ${ }^{23-25}$. In the NSABP B-06 study, the addition of chemotherapy to lymph nodenegative patients undergoing BCS was shown to reduce local recurrence ${ }^{25}$. It was reported that the administration of chemotherapy after BCS reduces local recurrence by $80 \%$, even in earlystage patients ${ }^{26}$. In the NSABP B-14 study, the addition of tamoxifen to the treatment protocol in patients with positive estrogen receptors was also shown to reduce local recurrence ${ }^{27}$. Although we did not make such a comparison in our study, chemotherapy was given to patients other than $\mathrm{T} 1$ and tamoxifen was given to patients with positive estrogen receptors.

There are many studies reporting that surgical margin positivity also increases the local recurrence rate r-28. $^{25}$.

It has been shown that the disease-related survival rate decreases in patients with local recurrence. Although it has been claimed that MRM application after BCS provides an adequate survival rate, some authors say that recurrence after BCS is a symptom of poor prognosis, as in recurrence after MRM26-29.

Only $5 \%$ of breast cancers are reported to have a genetic predisposition. It is controversial whether high-risk women are suitable for BCS in terms of family history or background (not having given birth or not having breastfed). In a 
study conducted by the Geneva Familial Breast Cancer Registry, there was not differentiation in terms of five-year survival among patients with the family history (58 patients) and those no family history (575 patients) ${ }^{28}$. However, in another study, local recurrence rates after BCS were found to be higher in patients with hereditary breast cancer crosscheck to sporadic cases $^{29}$. In another study in which women who had breast cancer (131 patients) with BRCA1 and BRCA2 mutations were compared with women without a hereditary predisposition (261 patients), local area recurrence after BCS was similar, and this similarity was attributed to the hypothesis that patients with a family history might be more sensitive to radiotherapy. As a result of this study, the authors concluded that they could recommend BCS to women patients with breast cancer who had a family history ${ }^{30}$. In our study, although there is no patient with a family history, we recommend MRM to high-risk patients in terms of family history or background in accordance with our protocol in our clinic.

In conclusion, in our study with a limited number of patients, BCS provides a survival rate similar to MRM in patients without early-stage lymph node involvement, and we think that it is a preferred surgical treatment method in appropriate patients with patient satisfaction.

Ethics Committee Approval: The research was approved by University Ethics Committee with the number 10.11.2018.E.3955.

Declaration of Conflicting Interests: The authors declare that they have no conflict of interest.

Financial Disclosure: No financial support was received.
1. Shah C, Al-Hilli Z, Schwarz G. Oncoplastic surgery in Breast Cancer: Don't forget the Boost. Ann Surg Oncol. 2018; 25: 2509-11.

2. Valero MG, Mallory MA, Losk K, et al. Surgeon Variability and Factors Predicting for Reoperation Following Breast-Conserving Surgery.Ann Surg Oncol. 2018; 25: 2573-8.

3. Halsted WS. The results of radical operations for the cure of carcinoma of the breast. Ann Surg, 1907; 46: 1-19.

4. Fisher B, Bauer M, Margolese R, et al. Five-years results of a randomized clinical trial comparing total mastectomy with or without radiation in the treatment of breast cancer. N Engl J Med, 1985; 312: 665-73.

5. Riedel F, Hennigs A, Hug S, et al. Is Mastectomy Oncologically Safer than Breast-Conserving Treatment in Early Breast Cancer? Breast Care (Basel). 2017; 12: 385-90.

6. Poitevin-Chacón MA, Ramos-Prudencio R, Rumoroso-García JA, et al. Voluntary breath-hold reduces döșe to organs at risk in radiotherapy of left-sided breast cancer.Rep Pract Oncol Radiother. 2020; 25: 104-8.

7. Çiftci $F$, Anuk T. İdiopatik granulomatöz mastit: Zor tanı ve yönetim. Dicle Tıp Dergisi. 2017; 44: 167 74.

8. Houssami N, Turner RM, Morrow M. Meta-analysis of pre-operative magnetic resonance imaging (MRI) and surgical treatment for breast cancer. Breast Cancer Res Treat. 2017; 165: 273-83.

9. Dasgupta P, Youl PH, Pyke C, et al. Sentinel node biopsy for early breast cancer in Queensland, Australia, during 2008-2012. ANZ J Surg. 2018; 88: 400-5.

10. Weber WP, Soysal SD, El-Tamer M, et al. First international consensus conference on standardization of oncoplastic breast conserving surgery. Breast Cancer Res Treat. 2017; 165: 13949.

11. Jung SP, Hur SM, Lee SK, et al. Erratum: Validation of a Web-Based Tool to Predict the Ipsilateral Breast Tumor Recurrence(IBTR! 2.0) after Breast-Conserving Therapy for Korean Patient. Breast Cancer. 2017; 20: 117-25. 
12. Milulescu A, Di Marino L, Peradze N, et al. Management of Multifocal-Multicentric Cancer: Current Perspective. Chirurgia (Bucur). 2017; 112: 12-7.

13. Polgár C, Ott OJ, Hildebrandt G, et al. Groupe Européen de Curiethérapie of European Society for Radiotherapy and Oncology (GEC-ESTRO). Late side-effects and cosmetic results of accelerated partial breast irradiation with interstitial brachytherapy versus whole-breast irradiation after breast-conserving surgery for low-risk invasive and in-situ carcinoma of the female breast: 5-year results of randomised, controlled, phase 3 trial. Oncol. 2017;18: 259-68.

14. Fraser VJ, Nickel KB, Fox IK, et al. The Epidemiology and Outcomes of Breast Cancer Surgery.Trans Am Clin Climatol Assoc. 2016; 127: 46-58.

15. Zhou X, Li Y. Local Recurrence after BreastConserving Surgery and Mastectomy Following Neoadjuvant Chemotherapy for Locally Advanced Breast Cancer- a Meta- Analysis. Breast Care (Basel). 2016; 11: 345-51.

16. Mele A, Mehta P, Slanetz PJ, et al. BreastConserving Surgery Alone for Ductal Carcinoma In Situ: Factors Associated with Increased Risk of Local Recurrence. Ann Surg Oncol. 2017; 24: 1221-1226.

17. van Maaren MC, de Munck L, Jobsen JJ, et al. Breast conserving therapy versus mastectomy in T1-2N2 stage breast cancer: a population-based study on 10-year overall, relative, and distant metastasis-free survival in 3071 patients. Breast Cancer Res Treat. 2016; 160: 511-21.

18. De La Cruz L, Blankenship SA, Chatterjee A, et al. Outcomes After Oncoplastic Breast-Conserving Surgery in Breast cancer Patients: A systematic literature review. Ann Surg Oncol. 2016; 23: 324758.

19. Ang SC, Tapia G, Davidson EJ, et al. Positive anterior margins in breast conserving surgery: Does it matter? Asystematic review of the literature. Breast. 2016; 27: 105-8.

20. Yang JF, Lee MS, Lin CS, et al. Long-Term Breast Cancer Patient Outcomes After Adjuvant Radiotherapy Using Intensity-Modulated Radiotherapy or Conventional Tangential
Radiotherapy. Medicine (Baltimore). 2016; 95:3113-17.

21. Zervoudis S, Iatrakis G, Mares $P$, et al. Breast conserving surgery in multicentricbreast cancer, preliminary data of our experience. Eur J Gynaecol Oncol. 2014; 35: 530-4.

22. Kummerow KL, Du L, Penson DF, et al. Nationwide trends in mastectomy for early-stage breast cancer.JAMA Surg. 2015;150:9-16.

23. Wilke LG, Czechura T, Wang C,et al. Repeat surgery after breast conservation fort he treatment of stage 0 to II breast carcinoma: a report from the National Cancer Data Base, 2004-2010. JAMA Surg. 2014; 149: 1296-305.

24. Vila J, Garcia-Etienne CA, Vavassori A, et al.Conservative surgery for ipsilateral breast tumor recurrence. J Surg Oncol. 2014; 110: 62-7.

25. Martelli G, Boracchi P, Orenti A, et al. Axillary dissection versus no axillary dissection in older T1N0 breast cancer patients: 15-year results of trial and out-trial patients. Eur J Surg Oncol. 2014; 40: 805-12.

26. Bhatti AB, Khan AI, Siddiqui N, et al. Outcomes of triple-negative versus non-triple-negative breast cancers managed with breast-conserving therapy. Asian Pac J Cancer Prev. 2014; 15: 2577-81.

27. Warren LEG, Chen YH, Halasz LM, et al. Longterm outcomes of breast-conserving therapy for womenwith ductal carcinoma in situ. Breast Cancer Res Treat. 2019; 178: 607-15.

28. Tovar JR, Zandonade E, Amorim MHC. local recurrence-free survival in women with breast cancer who undergo breast-concerving surgery. Breast J. 2019; 25: 1042-4.

29. Verkooijen HM, Chappuis PO, Rapiti E, et al. Impact of familial risk factors on management and survival of early-onset breast cancer: a populationbased study. Br J Cancer, 2006; 94: 231-8.

30. Kirova YM, Stoppa_Lyonnet D, Savignoni A, et al. Risk of breast cancer recurrence and contralateral breast cancer in relation to BRCA1 and BRCA2 mutation status following breast-conserving surgery and radiotherapy. Eur J Cancer, 2005; 41: 2301-11. 